\title{
PRODUCTION OF MULTIFUNCTIONAL FOOTWEAR FOR PRISON POLICE OFFICERS
}

\section{Mirela PANTAZI-BĂJENARU*, Traian FOIAŞI, Dana GURĂU}

INCDTP - Division: Leather and Footwear Research Institute, 93 Ion Minulescu, 031215 Bucharest, Romania, pantazimirela@yahoo.com

Received: 29.10 .2020

Accepted: 11.03 .2020

https://doi.org/10.24264/Ifj.20.1.7

PRODUCTION OF MULTIFUNCTIONAL FOOTWEAR FOR PRISON POLICE OFFICERS

ABSTRACT. There is a close connection between the comfort in wearing footwear and the quality of this product. When we refer to the quality of footwear, we must start from the analysis of materials used to make the upper and lower shoe assembly, the analysis of how the joints between the different elements of the assembly behave and finally we must consider the behavior of the shoes as a whole. The footwear must create a climate where temperature, humidity, air circulation and their action on the foot, and on the whole body are correlated. Even at a rapid change of internal or external influences, the wearer must feel good. The so-called triple physiological agreement - temperature, humidity and air circulation - must be adaptable to various requirements during a working day such as: rest, movement, physical effort and climatic conditions. The design of a product is not only related to the aesthetic, artistic aspect, but more to its functionality and engineering (from the correct choice of materials, construction and technological concept, to prototyping). A good example in this regard is the design of multifunctional footwear, for soldiers and police officers. Therefore, designing the right footwear is a big challenge not only for designers, but also for engineers. The paper presents the way in which footwear as a component of the work uniform of prison police officers was made. KEY WORDS: multifunctional footwear, materials, specifications

\section{DEZVOLTAREA ÎNCĂLTĂMINTEI MULTIFUNCTIONALE PENTRU POLITIŞTII DE PENITENCIARE}

REZUMAT. Există o strânsă legătură între confortul pe care purtarea unui produs de încălțăminte îl conferă utilizatorului şi calitatea acestui produs. Când ne referim la calitatea unui produs de încălţăminte trebuie să pornim de la analiza materialelor destinate confecționării ansamblului superior şi inferior al încălțămintei, analiza modului în care se comportă îmbinările dintre diferitele elemente ale ansamblului şi în final trebuie să avem în vedere comportarea produsului de încălţăminte în ansamblu. Încălţămintea trebuie să creeze un climat unde să fie corelate temperatura, umiditatea, circulația aerului şi acțiunea lor asupra piciorului, respectiv a întregului organism. Chiar la o schimbare rapidă a influenţelor interioare sau exterioare, purtătorul trebuie să se simtă bine. Așa numitul acord triplu fiziologic - temperatura, umiditatea şi circulația aerului - trebuie să fie adaptabil cerințelor diverse din timpul unei zile de lucru cum ar fi: odihnă, mișcare, efort fizic şi condițiile climatice. Proiectarea unui produs nu este legată doar de aspectul estetic, artistic, ci mai mult de funcționalitatea și ingineria sa (de la alegerea corectă a materialelor, construcției și conceptului tehnologic, până la prototipare). Un bun exemplu în acest sens este proiectarea încălțămintei multifuncționale, încălțăminte pentru soldați, polițiști. Prin urmare, proiectarea încălțămintei adecvate reprezintă o provocare mare nu numai pentru designeri, dar și pentru ingineri. Lucrarea prezintă modul în care a fost realizată încălțămintea din componența uniformei de serviciu a polițiștilor de penitenciare.

CUVINTE CHEIE: încălţăminte multifuncţională, materiale, specificații

\section{DÉVELOPPEMENT DE CHAUSSURES MULTIFONCTIONNELLES POUR DES AGENTS DE POLICE DES PRISONS}

RÉSUMÉ. II existe un lien étroit entre le confort des chaussures et la qualité de ce produit. Lorsque nous nous référons à la qualité des chaussures, nous devons partir de l'analyse des matériaux destinés à fabriquer l'ensemble supérieur et inférieur de la chaussure, l'analyse du comportement des combinaisons entre les différents éléments de l'ensemble et enfin nous devons considérer le comportement des chaussures dans son ensemble. Les chaussures doivent créer un climat où la température, l'humidité, la circulation de l'air et leur action sur le pied, et respectivement sur le corps entier sont corrélées. Même lors d'un changement rapide d'influences internes ou externes, le porteur doit se sentir bien. Le soi-disant triple accord physiologique - température, humidité et circulation de l'air - doit être adaptable à diverses exigences au cours d'une journée de travail telles que: repos, mouvement, effort physique et conditions climatiques. La conception d'un produit n'est pas seulement liée à l'aspect esthétique, artistique, mais plus à sa fonctionnalité et à son ingénierie (du choix correct des matériaux, de la construction et du concept technologique au prototypage). Un bon exemple à cet égard est la conception de chaussures multifonctionnelles pour les soldats et les agents de police. Par conséquent, la conception des chaussures appropriées est un grand défi non seulement pour les concepteurs, mais aussi pour les ingénieurs. Le document présente la façon dont les chaussures pour l'uniforme de service des agents de police des prisons ont été fabriquées.

MOTS CLÉS : chaussures multifonctionnelles, matériaux, spécifications

* Correspondence to: Mirela PANTAZI-BĂJENARU, INCDTP - Division: Leather and Footwear Research Institute, 93 lon Minulescu, 031215 Bucharest, Romania, pantazimirela@yahoo.com 


\section{INTRODUCTION}

Footwear protects human feet against harsh conditions, such as cold or hot environments, wet surfaces, etc. Over time, there have been many changes in design, materials and technologies used, all of these in order to meet the needs of end users, from fashion to comfort and protection. That is why, today, there are a lot of types of footwear on the market, each with its own specific characteristics, e.g. sports shoes, trekking/hiking shoes, summer shoes, safety shoes, work shoes, etc. A special type of footwear is for soldiers and police officers, which is used in different environmental conditions (for cold and/or hot weather).

Military footwear has to fulfill many specific requirements, from maintaining and improving mobility to maximizing protection and eliminating or minimizing the risk to the wearer (protection against ballistics, low temperatures, heat, degradation of human perspiration or microbiological agents, insects and snake bites etc.). Therefore, designing proper military footwear represents a major challenge not only for designers, but also for engineers.

When developing new products, considerable efforts must be made in designing the process, from the correct choice of materials, construction type and technological concept, to prototypes and consumer preferences (Figure 1) [1]. Only in this way the new product will be designed and functionalized according to the needs and requirements of the end user.

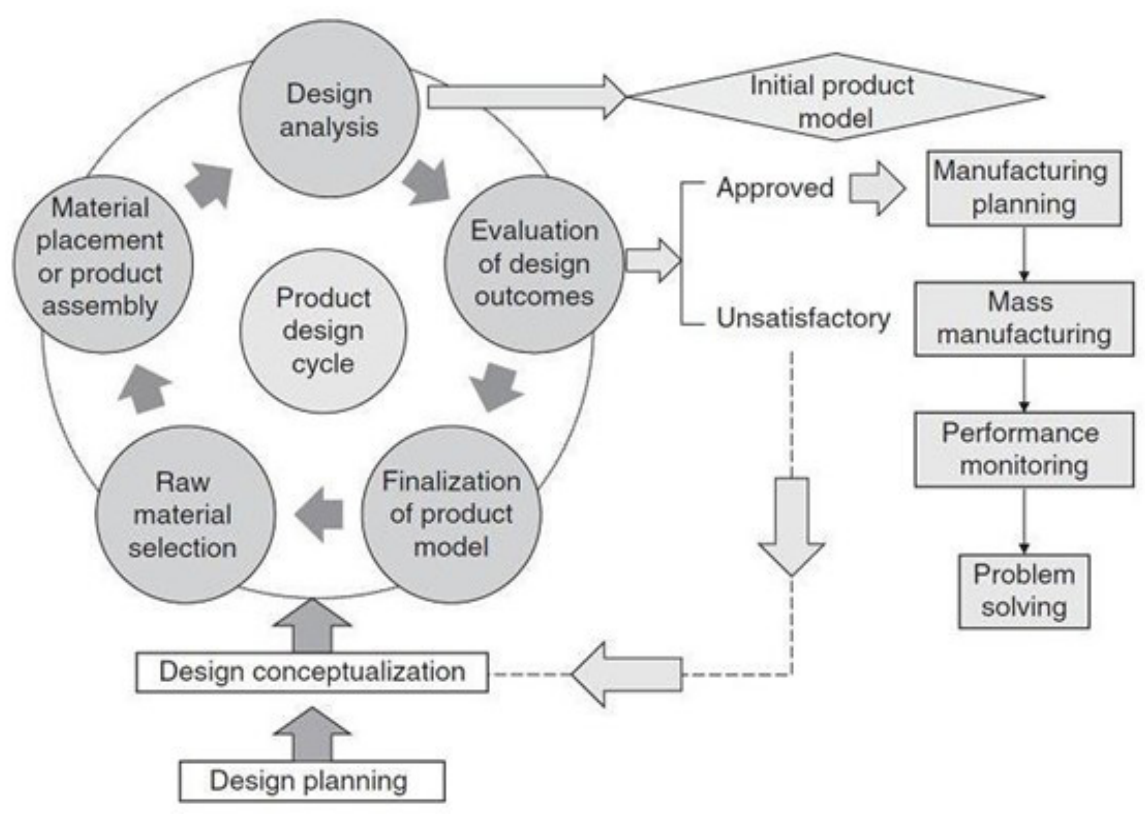

Figure 1. Product design concept

The process of designing specific products (for example, protective clothing or footwear) includes the entire design activity for the development of new products with high technological content, from the initial idea and the first project concept to the feasibility analysis, taking into account the materials to be tested during design, prototyping and manufacturing [2]. Designing specific products means balancing design requirements with function, performance, protection and comfort $[3,4]$. This paper presents the development of boots for hot and cold climatic conditions, specifically for the work uniform of police officers working in prisons.

\section{EXPERIMENTAL}

The purpose of the study is to develop multifunctional footwear for prison police officers, which can be worn in different climatic conditions, both during hot and cold weather. According to the common product design cycle (Figure 1), the design analysis, the material 
selection, the product assembly mode, the evaluation of the design results, the prototyping, the prototype testing in real environment and the prototype corrections were performed according to the preferences and recommendations of the end user. As a result of such an integrated and iterative process of product development, a multifunctional product is developed for hot and cold weather conditions.

\section{RESULTS AND DISCUSSIONS}

As a result of a survey on functionality, ergonomics, comfort, protection, shape, weight, etc. conducted among the end users the sketch of the boots that are part of the work uniform was made (Figure 2).

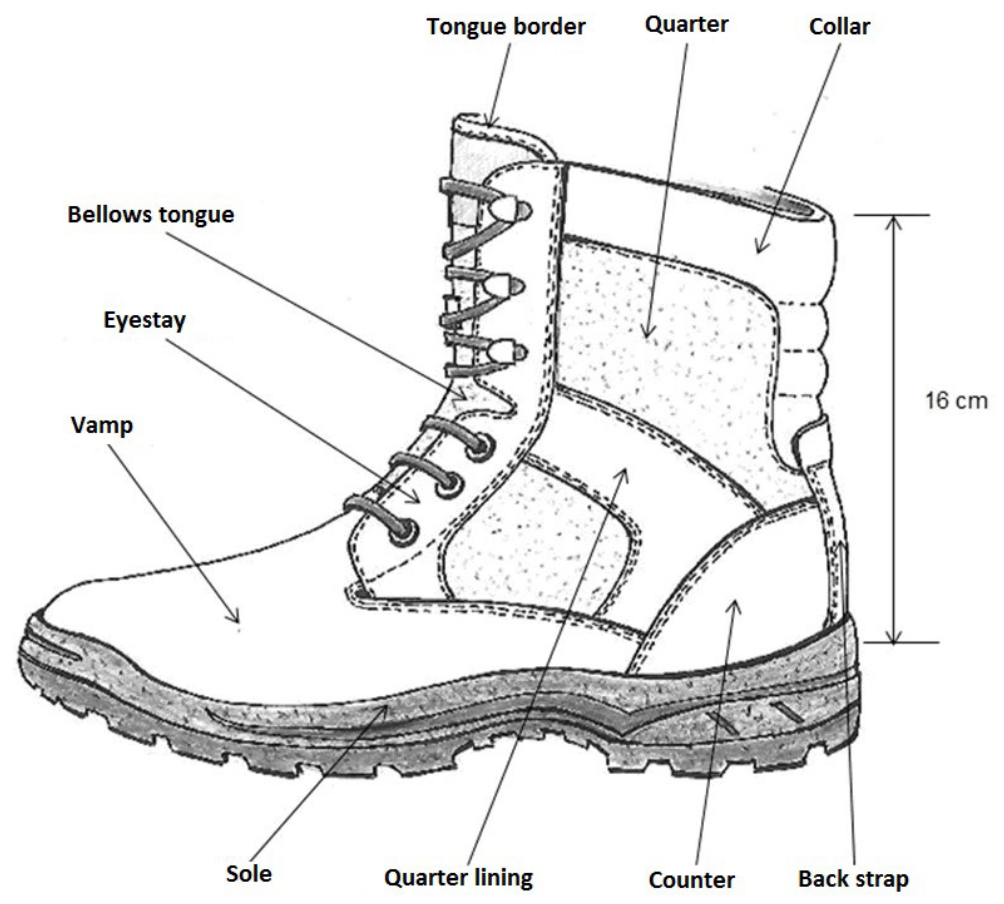

Figure 2. Sketch of the boots used as part of work uniform

Because there are many different component parts that make up the product, it is very important to choose the right materials that meet all end-user requirements regarding tensile strength, flexural strength, hardness, abrasion, etc., while ensuring adequate comfort for the wearer, both in hot and cold environments. In addition, the materials for all 70 component parts must be able to be combined together, ensuring aesthetic and functional value, as well as comfort.

Thus, the shoe uppers are made of natural black bovine leather (vamp, counter, back strap, collar, quarter lining, eyestay, eyestay lining), but also of textile material (quarters and tongue). Both leather and textile material are chemically waterproofed.

The upper leather must be waterproof, with a thickness of 1.8 to $2 \mathrm{~mm}$, so that it can meet the parameters related to tear strength and load resistance. These parameters influence the quality, strength, elasticity and plasticity during the manufacturing process and on the final product - the boots. Also, according to environmental standards, the chromium content should be undetectable. Other parameters (water permeability, water absorption, water vapor permeability) are closely related to foot comfort when wearing boots.

The textile material for uppers is a Cordura-type fabric and must be resistant to water penetration.

The inner linings are made of pig basan (counter lining), but also of textile material (quarter lining, vamp and tongue). The linings are stitched in a zig zag pattern and the seams are heat sealed. 
The intermediate linings are made of a thermo-adhesive textile material (vamp reinforcement and quarter reinforcement), a self-adhesive material (eyestay) and a selfadhesive sponge (intermediate collar lining and intermediate tongue lining).

The sole is bicomponent (rubber + polyurethane), directly injected into the double density system. The outer layer has a high density which ensures increased wear resistance. The inner layer has a lower average density than the outer layer, which ensures an elasticity that takes over the mechanical shocks and allows an efficient distribution of body weight. The outsole has a non-slip appearance with regular shapes on the outer surface. No bumps or irregularities are allowed on the visible side of the sole.

The locking system is stitching with eyelets and a black cotton lace.

The boots are made using the injection system (shoes with soles directly injected on the uppers).

No metallic elements are allowed in the boots, in order not to elicit a false alarm during antiterrorist and specialized control, when accessing the penitentiary.

Table 1 presents the characteristics of the materials used to make the boots as part of the work uniform of prison police officers.

Table 1: Characteristics of materials used to make the boots for prison police officers

\begin{tabular}{|c|c|c|c|c|}
\hline No. & Material & Size (mm) & Nature of material & Use \\
\hline 1. & $\begin{array}{l}\text { Natural bovine black leather, } \\
\text { smooth grain, chemically } \\
\text { waterproofed }\end{array}$ & 1.8-2 (thickness) & Bovine leather & Vamp, counter, back strap, collar \\
\hline 2. & $\begin{array}{l}\text { Natural bovine black leather, } \\
\text { smooth grain, chemically } \\
\text { waterproofed }\end{array}$ & 1.2-1.4 (thickness) & Bovine leather & $\begin{array}{l}\text { Quarter lining, eyestay, eyestay } \\
\text { lining }\end{array}$ \\
\hline 3. & $\begin{array}{l}\text { Double layer Cordura } \\
\text { waterproof fabric }\end{array}$ & 3 (thickness) & Synthetic & Quarters \\
\hline 4. & $\begin{array}{l}\text { Simple Cordura waterproof } \\
\text { fabric }\end{array}$ & 0.5 (thickness) & Synthetic & Bellows tongue \\
\hline 5. & $\begin{array}{l}\text { Textile material doubled with } \\
\text { polyurethane foam }\end{array}$ & 1.6 (thickness) & Synthetic & $\begin{array}{l}\text { Inner lining for quarters, vamp } \\
\text { and tongue }\end{array}$ \\
\hline 6. & Self-adhesive sponge & 8 (thickness) & Synthetic & Intermediate lining for collar \\
\hline 7. & Self-adhesive sponge & 6 (thickness) & Synthetic & Intermediate lining for tongue \\
\hline 8. & Thermoadhesive fabric & 0.4-0.5 (thickness) & Cotton & $\begin{array}{l}\text { Reinforcement for vamp and } \\
\text { quarters }\end{array}$ \\
\hline 9. & Self-adhesive reinforcement & 0.4-0.5 (thickness) & Non-woven textile & Reinforcement for eyelets \\
\hline 10. & Cotton strap & 12 (width) & Cotton & Tongue border \\
\hline 11. & Self-adhesive strap & 10 (width) & Synthetic & Sealing the stitches \\
\hline 12. & $\begin{array}{l}\text { Thermoadhesive } \\
\text { reinforcement }\end{array}$ & 1.7 (thickness) & Thermoplastic material & Toe-cap \\
\hline 13. & $\begin{array}{l}\text { Thermoadhesive } \\
\text { reinforcement }\end{array}$ & 2 (thickness) & Thermoplastic material & Rigid counter \\
\hline 14. & Tubular cotton laces & 1300 (length) & Cotton & Lacing \\
\hline 15. & $\begin{array}{l}\text { Expanded EVA doubled with } \\
\text { textile material, preformed }\end{array}$ & 2.2 (thickness) & EVA + synthetic & Insole cover \\
\hline 16. & Synthetic thread & $\begin{array}{l}30 / 3 \mathrm{Nm} \\
40 / 3 \mathrm{Nm}\end{array}$ & Synthetic & Sewing uppers and linings \\
\hline 17. & Black round eyelets & $\varnothing 5 \mathrm{~mm}$ & $\begin{array}{l}\text { Plastic / composite } \\
\text { material with high } \\
\text { hardness }\end{array}$ & Lacing, 12 pcs/pair \\
\hline
\end{tabular}



18. Hooks for lacing
material with high hardness
19. Adhesives
Manual solution
Lacing, 12 pcs/pair
Rubber + Polyurethane
Upper gluing
20. Injected sole
21. Colourless wax
Finishing
22. Dye for upper retouching
Retouches

Plastic / composite

Table 2 presents the requirements that the finished product. must be met by materials used for the boots and

Table 2: Physical-mechanical parameters required for the materials and the finished product

\begin{tabular}{|c|c|c|c|}
\hline Specifications & Standard & $\mathrm{U} / \mathrm{M}$ & Imposed values \\
\hline \multicolumn{4}{|l|}{ Leather } \\
\hline Tensile strength & SR EN ISO 3376:2012 & $\mathrm{N} / \mathrm{mm}^{2}$ & $\min .24$ \\
\hline $\begin{array}{l}\text { Water resistance of flexible leather } \\
\text { - absorption after } 3 \mathrm{~h} \\
\text { - amount of water passed through the leather }\end{array}$ & SR EN ISO 5403-1:2012 & $\begin{array}{c}\% \\
g / h\end{array}$ & $\begin{array}{l}\max .45 \\
\max .2 .5\end{array}$ \\
\hline Water vapour permeability & SR EN ISO 14268:2013 & $\mathrm{mg} / \mathrm{cm}^{2} \mathrm{~h}$ & $\min .0 .8$ \\
\hline Flexural strength & SR EN ISO 5402-1:2012 & cycles & 250000 \\
\hline \multicolumn{4}{|l|}{ Sole } \\
\hline $\begin{array}{l}\text { Hardness } \\
\text { - outer layer } \\
\text { - inner layer }\end{array}$ & SR ISO 7619-1:2011 & ${ }^{\circ} \mathrm{Sh} A$ & $\begin{array}{l}70 \pm 5 \\
60 \pm 5\end{array}$ \\
\hline Abrasion strength & SR EN 12770:2002 & $\mathrm{mm}^{3}$ & $\max .250$ \\
\hline Flexural strength & SR EN ISO 17707:2005 & cycles & 100000 \\
\hline \multicolumn{4}{|l|}{ Material for quarters } \\
\hline Resistance to water penetration & SR EN 811:2018 & $\mathrm{mm}$ col. water & $\min .10000$ \\
\hline \multicolumn{4}{|l|}{ Bellows tongue material } \\
\hline Moisture resistance (Spray-test) & SR EN ISO 4920:2013 & note & $\min .4$ \\
\hline \multicolumn{4}{|l|}{ Lining } \\
\hline Tear strength & SR EN ISO 13937-3:2002 & $\mathrm{N}$ & $\min .20$ \\
\hline Abrasion strength & SR EN ISO 12947-2:2017 & no. of cycles & $\min .25000$ \\
\hline \multicolumn{4}{|l|}{ Finished product } \\
\hline Leather upper and sole peel resistance & SR EN ISO 17708:2004 & $\mathrm{N} / \mathrm{mm}$ & $\min .4$ \\
\hline
\end{tabular}

In accordance with the specified materials and the chosen technology, the prototypes were made and offered to the volunteers for real field tests in hot and cold environment. The feedback was positive from almost all users, which meant that all their requests and expectations were met, although some suggested that the size of the boots could be better adjusted to the type of foot (narrower, wider, etc.). Based on these results, the final shape of the multifunctional boots for hot and cold weather conditions (Figure 3) was established. They will be standard equipment for prison police officers, as they are comfortable and durable boots. 

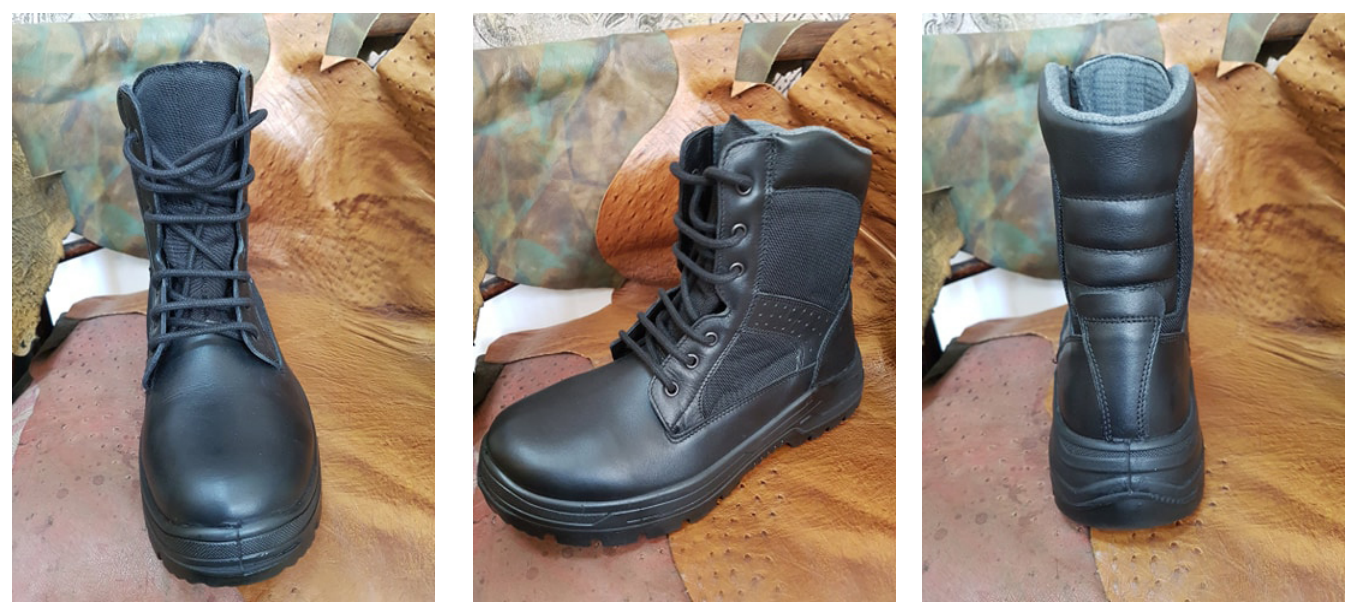

Figure 3. Multifunctional footwear for hot and cold weather

\section{CONCLUSIONS}

The production of a type of footwear that can be worn even in hot and cold weather conditions, intended for use during service by the penitentiary police officers, proved to be possible by the multifunctional design of a new product, made through the interdisciplinary team work of engineers and designers, in accordance with the requirements and suggestions of end users.

\section{Acknowledgements}

This study was funded by the Minister of Research and Innovation through the Program 1 - Development of the National Research and Development System, Subprogram 1.2 - Institutional Performance - RDI excellence funding projects, Contract no. 6PFE/16.10.2018.

\section{REFERENCES}

1. El Mogahzy, Y.E., Engineering textiles, Cambridge: Woodhead Publishing Limited, 2009, p. 68.

2. Pantazi, M., Vasilescu, A.M., Establishing Anthropometric Foot Sizes of the Male Population in Romania in Order to Develop an Original Romanian Standard, Proceedings of The 7th International Conference on Advanced Materials and Systems - ICAMS 2018, ISSN: 2068-0783, CERTEX Press, pp. 385-390, https://doi.org/10.24264/ icams-2018.VII.2.

3. Dammaco, G. et al., Design of Protective Clothing Functional Protective Textiles, chapter 1, S. Bischof Vukušić (Ed.), Zagreb: University of Zagreb Faculty of Textile Technology, pp. 1-32, 2012.

4. Deselnicu, D.C., Pantazi, E.M., Costea, M., Purcarea, A.A., Militaru, G., Multi-Criteria Analysis of Biomechanical Parameters Used for Developing Innovative Products, Procedia Engineering, Volume 181, ISSN 18777058, 2017, pp. 96-101, 10th International Conference Interdisciplinarity in Engineering, INTER-ENG 2016, 6-7 October 2016, Tirgu Mures, Romania, https://doi.org/10.1016/j. proeng.2017.02.373.

(C) 2020 by the author(s). Published by INCDTPICPI, Bucharest, RO. This is an open access article distributed under the terms and conditions of the Creative Commons Attribution license (http:// creativecommons.org/licenses/by/4.0/). 